\title{
Inorganic carbon addition stimulates snow algae primary productivity
}

\author{
Trinity L. Hamilton ${ }^{1}$ Jeff R. Havig ${ }^{2}$
}

Received: 9 August 2017 / Revised: 6 December 2017 / Accepted: 21 December 2017 / Published online: 29 January 2018

(c) The Author(s) 2018. This article is published with open access

\begin{abstract}
Earth has experienced glacial/interglacial oscillations accompanied by changes in atmospheric $\mathrm{CO}_{2}$ throughout much of its history. Today over 15 million square kilometers of Earth's land surface is covered in ice including glaciers, ice caps, and ice sheets. Glaciers are teeming with life and supraglacial snow and ice surfaces are often darkened by the presence of photoautotrophic snow algae, resulting in accelerated melt due to lowered albedo. Few studies report the productivity of snow algal communities and the parameters which constrain their growth on supraglacial surfaces-key factors for quantifying biologically induced albedo effects (bio-albedo). We demonstrate that snow algae primary productivity is stimulated by the addition of inorganic carbon. Our results indicate a positive feedback between increasing $\mathrm{CO}_{2}$ and snow algal primary productivity, underscoring the need for robust climate models of past and present glacial/interglacial oscillations to include feedbacks between supraglacial primary productivity, albedo, and atmospheric $\mathrm{CO}_{2}$.
\end{abstract}

Earth has experienced intervals of glacial and interglacial periods in its history including Snowball Earth events [1,2]. Today, glaciers and ice sheets are integral to the Earth's climate and hydrological system-they influence regional and global climate, are sensitive to climate change, and are the largest freshwater reservoir on Earth [3, 4]. Geologic and geochemical evidence suggest that glacial/interglacial oscillations are coincident with lower atmospheric $\mathrm{CO}_{2}$ [5] and are exacerbated by lower solar luminosity [6]. For instance, models indicate overcoming high planetary albedo during Snowball Earth events required greenhouse warming caused by the accumulation of high levels of $\mathrm{CO}_{2}$ from volcanic outgassing accompanied by decreases in silicate weathering $[7,8]$. Due to human activity, atmospheric $\mathrm{CO}_{2}$ is now above $400 \mathrm{ppm}$ [9] and from 1999 to $2010, \mathrm{CO}_{2}$ was

Electronic supplementary material The online version of this article (https://doi.org/10.1038/s41396-018-0048-6) contains supplementary material, which is available to authorized users.

Trinity L. Hamilton

trinityh@umn.edu

1 Department of Plant and Microbial Biology, University of Minnesota, St. Paul, MN 55108, USA

2 Department of Earth Sciences, University of Minnesota, Minneapolis, MN 55455, USA emitted at a rate 100 times as fast as during the last glacial termination [10]. Coincident with increasing $\mathrm{CO}_{2}$, average global temperatures have increased $\left(\sim{ }^{\circ} \mathrm{C}\right.$ over the past century) leading to glacial retreat and receding snowpack.

Glaciers and ice sheets are a host to diverse ecosystems including supraglacial communities that contribute to local and global biogeochemical cycles [11]. Snow algae (eukaryotic photoautotrophs) are key primary producers on supraglacial habitats in the Arctic, and on glaciers and snowfields throughout the world where they thrive in highirradiation environments $[12,13]$. To overcome this high irradiance, snow algae produce secondary carotenoids resulting in blooms of red algal biomass [14], which darkens snow and ice surfaces. In Sierra Nevada snowfields, snow algae abundance was negatively correlated to surface albedo [15] and a recent study quantified the role of snow algae communities in snowmelt on an icefield in Alaska [16]. Similarly, in the Arctic, red algal blooms darken the snow/ice surface, lowering surface albedo (by as much as $13 \%$ over the melt season) [17] and increasing melt rates $[18,19]$.

Allochthonous material delivered to snow and ice surfaces such as forest fire-derived black carbon, Saharan or pro-glacial mineral dust, volcanic ash, and anthropogenic pollution causes increased absorption of solar radiation and locally accelerated melting. These effects can be far reaching - a darkening of the Greenland ice sheet has been 
Fig. 1 Map of sampling site locations and composition of small subunit $16 \mathrm{~S}$ and $18 \mathrm{~S}$ rRNA gene sequences. OTUs for each library were binned at the Family level. Only OTUs which were present in $50 \%$ or more of the samples are presented

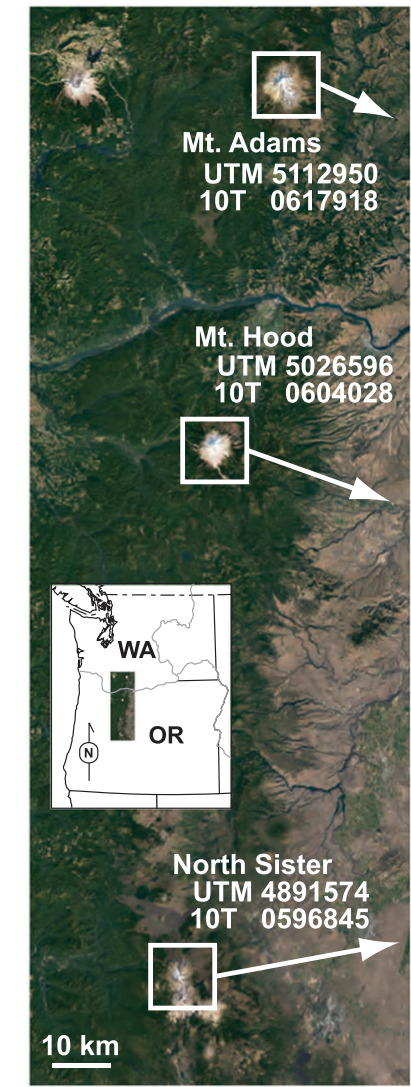

Eukarya (E) Legend

\begin{tabular}{|ll|}
\hline$\square$ Cerozoa & $\square$ Incertae Sedis \\
$\square$ Chlamydomonadaceae & $\square$ Leucosporidales \\
$\square$ Glissomonadida & $\square$ Microbotryomycetes \\
& $\square$ Prasiolales \\
\hline
\end{tabular}
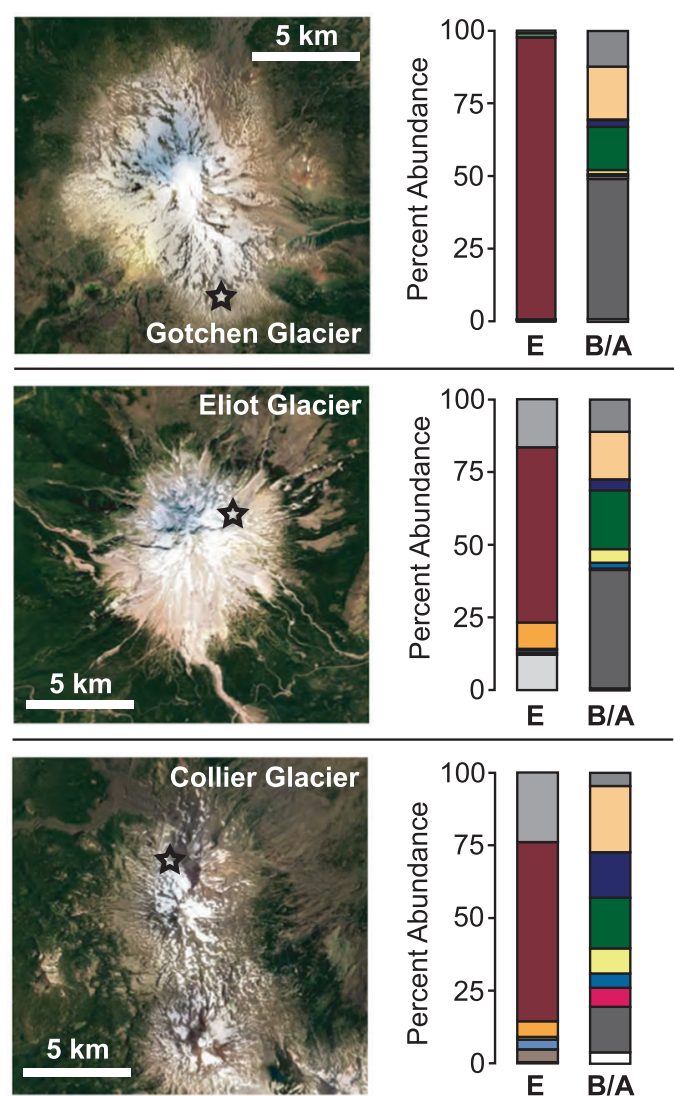

Bacteria and Archaea (B/A) Legend

\begin{tabular}{|ll|}
\hline Acetobacteraceae & $\square$ Microbacteriaceae \\
$\square$ Chitinophagaceae & Nakamurellaceae \\
Comamonadaceae & Nitrospiraceae \\
Cytophagaceae & $\square$ Sphingobacteriaceae \\
& $\square$ Unclassified Bacteria \\
\hline
\end{tabular}

observed coincident with increased melt [20]. While the effects of inorganic material on albedo have been quantified, climate models have not traditionally accounted for melting caused by snow algae [17]. These efforts are complicated by the difficulty in separating abiotic albedo from biologically induced darkening, or bio-albedo, as well as a paucity of data on snow algae distribution and density. However, a recently developed spectral model for bio-albedo which includes snow physical properties and meteorological data indicates that algal blooms can influence snowpack albedo and melt rate [19]. The model indicated that algae biomass has a greater effect than pigment concentration, suggesting a positive correlation between supraglacial algal blooms and accelerated melt. Consistent with this observation, a role for snow algae in lowering albedo through bio-geophysical feedback was also quantified on an icefield in Alaska where snow algae abundance increased with addition of either water or nutrients (a nitrogen-phosphorous-potassium fertilizer)[16].
Understanding both geologic glacial/interglacial oscillations and predicting future climate requires integrating climate models, carbon cycling, and planetary albedo. Algal clades, including green algae, evolved prior to Neoproterozoic glaciations [21]. Thus, the cosmopolitan nature of snow algae and their widespread distribution on snowpacks worldwide [22] facilitates their inclusion in these models across space and time. Snow algae is now recognized as a key component driving melting, yet the role of increasing $\mathrm{CO}_{2}$ on snow algae primary productivity (a proxy for growth), and thus albedo, remains unconstrained. Here we examined community composition and primary productivity (carbon fixation rates) of snow algae communities on supraglacial snowfields on glaciers on stratovolcanoes in the Pacific Northwest (USA). We targeted Gotchen Glacier on Mt. Adams, Eliot Glacier on Mt. Hood, and Collier Glacier on North Sister (Fig. 1; Table S1) where our previous data suggested photoautotrophic snow algae could be inorganic carbon-limited [23]. 

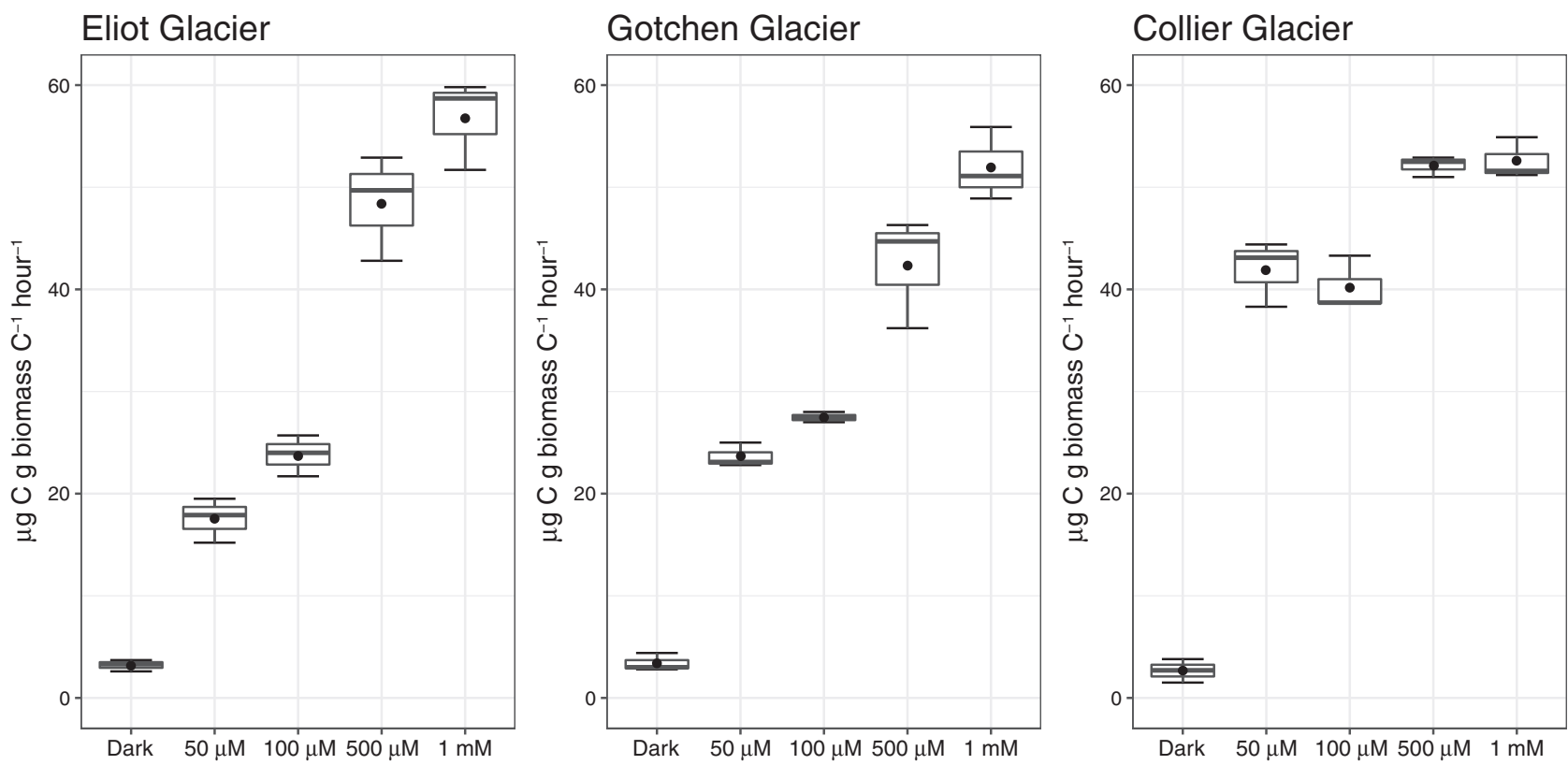

Fig. 2 Box-Whisker plots of carbon assimilation rates by supraglacial communities. The horizontal line in each box indicates the median and closed circles represent the mean $\left(n=3\right.$ for each treatment). Dark treatments were amended with $100 \mu \mathrm{M} \mathrm{NaH}{ }^{13} \mathrm{CO}_{3}$

\section{Stratovolcano supraglacial microbial community composition}

Snow algae assemblages were comprised predominantly of eukaryotic $18 \mathrm{~S}$ rRNA gene sequences affiliated with Chlamydomonas spp. and Chloromonas spp. within the Chlorophyta (green algae)(Fig. 1). OTUs affiliated with strains of Chlamydomonas nivalis were abundant in supraglacial snow from Gotchen and Eliot Glaciers whereas OTUs affiliated with a Chloromonas spp. were the most abundant in the Collier Glacier snow sample. The sequences recovered are similar to those recovered from the Arctic, further indicating snow algae are cosmopolitan [17]. Bacterial OTUs most closely related to Chitinophagaceae, Cytophagaceae, and Sphingobacteriaceae were abundant in snow algae samples from the three glaciers (Fig. 1). The recovery of these bacteria is consistent with previous studies of supraglacial snow [13, 17] (Hamilton and Havig, 2017) and highlights a role for these populations in degradation of complex organic carbon on the glacial surface.

\section{Stratovolcano snow algae primary productivity}

Carbon fixation rates were examined in a series of microcosms in supraglacial snow over a range of dissolved inorganic carbon (DIC) concentrations $(50 \mu \mathrm{M}$ to $1 \mathrm{mM}$ $\mathrm{NaH}^{13} \mathrm{CO}_{3}$ ) where natural DIC concentration in snow samples ranged from 10.6 to $46.3 \mu \mathrm{M}$ (Table S1). At all sites, an increase in light-dependent carbon fixation was observed with increasing concentration of DIC concentration (Fig. 2). In microcosms amended with $50 \mu \mathrm{M}$ $\mathrm{NaH}^{13} \mathrm{CO}_{3}$ (Fig. 2; Table S1), rates of carbon assimilation ranged from $\sim 17 \mu \mathrm{g} \mathrm{C} / \mathrm{g} \mathrm{C}_{\text {biomass }} / \mathrm{h}$ in supraglacial snow algae from Eliot Glacier to $\sim 42 \mu \mathrm{g} \mathrm{C} / \mathrm{g} \mathrm{C}_{\text {biomass }} / \mathrm{h}$ at Collier Glacier. Microcosms amended with $500 \mu \mathrm{M}$ or $1 \mathrm{mM}$ $\mathrm{NaH}^{13} \mathrm{CO}_{3}$ incorporated significantly more carbon than assays amended with $50 \mu \mathrm{M}$ or $100 \mu \mathrm{M} \mathrm{NaH}{ }^{13} \mathrm{CO}_{3}$ (Fig. 2; Table S1). This effect was particularly pronounced at Eliot and Gotchen Glaciers where rates increased $77-108 \%$ in the presence of elevated $\mathrm{NaH}^{13} \mathrm{CO}_{3}(50 \mu \mathrm{M}$ vs. $1 \mathrm{mM})$. The increase in carbon assimilation rates at Collier Glacier was less pronounced-we observed an increase of $\sim 20-25 \%$ in carbon assimilation between $50-100 \mu \mathrm{M} \mathrm{NaH}{ }^{13} \mathrm{CO}_{3}$ and 500 to $1 \mathrm{~mm} \mu \mathrm{M} \mathrm{NaH}{ }^{13} \mathrm{CO}_{3}$.

\section{Implications for future and past climate models}

Snow algae lower albedo and thus can alleviate water limitation by increasing meltwater [16]. As a result, increasing snow algae abundance acts as a positive feedback mechanism to accelerate melt. Here, we present data indicating snow algae primary productivity is stimulated by the addition of $\mathrm{CO}_{2}$. Assuming carbon fixation is a proxy for growth, our data suggest increasing atmospheric $\mathrm{CO}_{2}$ concentration will increase perennial snow algae abundance, serving as an additional positive feedback 
mechanism between snow algae and decreased albedo. These data underscore the need to quantify algal abundance in mountain glaciers which are particularly susceptible to climate change. Furthermore, these data add to the growing calls to quantify the effects of bio-albedo and the need for integrating algal-albedo interactions and variable (increasing) $\mathrm{CO}_{2}$ in models aimed at interpreting Earth's past glacial/interglacial oscillations as well as current and future climate models.

Acknowledgments We thank J. Miller and H. Roger for technical assistance in the field. We are particularly grateful to J. Miller. We thank the National Forest Service for facilitating access to the sample locations. We also thank B. Havig and S. Havig for their generosity in letting us use their home as a base of operations and their garage as a field laboratory. We are also grateful to A. Diefendorf for access to and use of the Stable Isotope Geochemistry Lab in the Department of Geology at the University of Cincinnati and C. Motley for assistance with processing samples. This research was supported by funds from the University of Cincinnati LEAF program, the University of Cincinnati, and the University of Minnesota.

Author contributions TLH and JRH designed the study, performed the field work, and completed all analyses. TLH wrote the manuscript with substantial input from JRH.

\section{Compliance with ethical standards}

Conflict of interest The authors declare that they have no conflict of interest.

Open Access This article is licensed under a Creative Commons Attribution 4.0 International License, which permits use, sharing, adaptation, distribution and reproduction in any medium or format, as long as you give appropriate credit to the original author(s) and the source, provide a link to the Creative Commons license, and indicate if changes were made. The images or other third party material in this article are included in the article's Creative Commons license, unless indicated otherwise in a credit line to the material. If material is not included in the article's Creative Commons license and your intended use is not permitted by statutory regulation or exceeds the permitted use, you will need to obtain permission directly from the copyright holder. To view a copy of this license, visit http://creativecommons. org/licenses/by/4.0/.

\section{References}

1. Hoffman PF, Kaufman AJ, Halverson GP, Schrag DP. A Neoproterozoic snowball earth. Science. 1998;281:1342-6. https://doi. org/10.1126/science.281.5381.1342

2. Rasmussen B, Bekker A, Fletcher IR. Correlation of Paleoproterozoic glaciations based on $\mathrm{U}-\mathrm{Pb}$ zircon ages for tuff beds in the Transvaal and Huronian Supergroups. Earth Planet Sci Lett. 2013;382:173-80. https://doi.org/10.1016/j.epsl.2013.08. 037

3. Clark PU, Alley RB, Pollard D. Northern hemisphere ice-sheet influences on global climate change. Science. 1999;286:1104-11. https://doi.org/10.1126/science.286.5442.1104

4. Edwards A, Irvine-Fynn T, Mitchell AC, Rassner SME. A germ theory for glacial systems? Wiley Interdiscip Rev Water. 2014;1:331-40. https://doi.org/10.1002/wat2.1029
5. Sigman DM, Boyle EA. Glacial/interglacial variations in atmospheric carbon dioxide. Nature. 2000;407:859-69. https://doi.org/ $10.1038 / 35038000$

6. Gough DO. Solar interior structure and luminosity variations. Sol Phys. 1981;74:21-34.

7. Allen PA, Etienne JL. Sedimentary challenge to Snowball Earth. Nat Geosci. 2008;1:817-25. https://doi.org/10.1038/ngeo355

8. Caldeira K, Kasting JF. Susceptibility of the early Earth to irreversible glaciation caused by carbon dioxide clouds. Nature. 1992;359:226-8. https://doi.org/10.1038/359226a0

9. Waters CN, Zalasiewicz J, Summerhayes C, Barnosky AD, Poirer C, Gałuszka A, et al. The Anthropocene is functionally and stratigraphically distinct from the Holocene. Science. 2016;351:aad2622 https://doi.org/10.1126/science.aad2622

10. Wolff EW. Greenhouse gases in the Earth system: a palaeoclimate perspective. Philos Trans A Math Phys Eng Sci. 2011;369:2133-47. https://doi.org/10.1098/rsta.2010.0225pmid:21502180

11. Anesio AM, Laybourn-Parry J. Glaciers and ice sheets as a biome. Trends Ecol Evolut. 2012;27:219-25. https://doi.org/10.1016/j. tree.2011.09.012

12. Morgan-Kiss RM, Priscu JC, Pocock T, Gudynaite-Savitch L, Huner NPA. Adaptation and acclimation of photosynthetic microorganisms of permanently cold environments. Microbiol Mol Biol Rev. 2006;70:222-52. https://doi.org/10.1128/MMBR. 70.1.222-252.2006

13. Boetius A, Anesio AM, Deming JW, Mikucki JA, Rapp JZ. Microbial ecology of the cryosphere: sea ice and glacial habitats. Nat Rev Microbiol. 2015;13:677-90. https://doi.org/10.1038/ nrmicro3522

14. Remias D, Lütz-Meindl U, Lütz C. Photosynthesis, pigments and ultrastructure of the alpine snow alga Chlamydomonas nivalis. Eur J Phycol. 2005;40:259-68. https://doi.org/10.1080/ 09670260500202148

15. Thomas WH, and Duval B. Sierra Nevada, California, USA, snow algae: snow albedo changes, algal-bacterial interrelationships, and ultraviolet radiation effects. Arctic and Alpine Research 1995;27:389-399.

16. Ganey GQ, Loso MG, Bryant Burgess A, Dial RJ. The role of microbes in snowmelt and radiative forcing on an Alaskan icefield. Nat Geosci. 2017;10:754-59. https://doi.org/10.1038/ngeo3027

17. Lutz S, Anesio AM, Raiswell R, Edwards A, Newton RJ, Gill F, et al. The biogeography of red snow microbiomes and their role in melting arctic glaciers. Nat Commun. 2016;7:11968 https://doi. org/10.1038/ncomms 11968

18. Musilova M, Tranter M, Bamber JL, Takeuchi N, Anesio AM. Experimental evidence that microbial activity lowers the albedo of glaciers. Geochem Perspect Lett. 2016;2:106-16. https://doi.org/ 10.7185/geochemlet.1611

19. Cook JM, Hodson AJ, Taggart AJ, Mernild SH, Tranter M. A predictive model for the spectral "bioalbedo" of snow. J Geophys Res Earth Surf. 2017;122:434-54. https://doi.org/10.1002/2016JF003932

20. Tedesco M, Doherty S, Fettweis X, Alexander P, Jeyaratnam J, Stroeve J. The darkening of the Greenland ice sheet: trends, drivers, and projections (1981-2100). Cryosphere . 2016;10:477-96. https://doi.org/10.5194/tc-10-477-2016

21. Knoll AH. The early evolution of eukaryotes: a geological perspective. Science. 1992;256:622-7. https://doi.org/10.1126/ science. 1585174

22. Hisakawa N, Quistad SD, Hester ER, Martynova D, Maughn H, Sala E, et al. Metagenomic and satellite analyses of red snow in the RussianArctic. Peer J. 2015;3:e1491. https://doi.org/10.7717/ peerj. 1491

23. Hamilton TL, Havig JR. Supraglacial primary productivity in glaciers on stratovolcanoes of the Pacific Northwest. Geobiology. 2017;15:280-295. https://doi.org/10.1111/gbi.12219. 